\title{
Strategi Kebijakan Pengembangan Sapi Potong Rakyat di Kecamatan Ringinrejo Kabupaten Kediri
}

\section{Strategy of Beef Cattle Development Policy at Ringinrejo Sub-District Kediri Regency}

\author{
J. A. Putritamara1*, M. B. Hariyono1, N. P. Sari2, \&Z. Fanani1 \\ ${ }^{1}$ Program Studi Sosial Ekonomi Peternakan, Fakultas Peternakan Universitas Brawijaya \\ ${ }^{2}$ Mahasiswa Pasca Ilmu Ternak, Fakultas Peternakan Universitas Brawijaya \\ Jl. Veteran, Ketawanggede, Kecamatan Lowokwaru, Kota Malang, Jawa Timur 65145 \\ *Email korespondensi: nichepermata@gmail.com
}

- Diterima: 17 Juni 2021 • Direvisi: 30 Agustus 2021 • Disetujui: 19 September 2021

\begin{abstract}
ABSTRAK. Penelitian bertujuan untuk menentukan strategi dan membentuk kebijakan yang bersifat win-win solution dalam mengembangkan usaha sapi potong rakyat di Kecamatan Ringinrejo Kabupaten Kediri. Analisis data yang digunakan dengan metode kuantitatif yaitu dengan menggunakan IFAS dan EFAS yang dilanjutkan dengan AHP (Analisis Hierarchy Process). Hasil penelitian menunjukkan pada kuadran III sehingga perlu membuat ulang strategi yang pernah dilakukan oleh stakeholders dalam mengembangkan usaha sapi potong, karena faktor internal memiliki kelemahan yang banyak dibandingkan dengan kekuatan yang ada, namun peluang yang ada dapat mengurangi ancaman dalam mengembangkan usaha. Hasil tersebut diperoleh 4 strategi antara lain dari startegi S-O bahwa perlu membangun kerjasama dengan peternak besar yang memiliki manajemen teknis pemeliharaan sapi potong yang sudah baik dan tingkat produktifitas usaha tinggi, strategi W-O memperbaiki hubungan peternak dengan lembaga pemerintah pusat melalui peningkatan aparatur dari modal sosial dengan memberikan bantuan ternak, teknis pemeliharaan sesuai dengan yang dibutuhkan peternak, strategi S-T bergabung dengan kelompok ternak feedloting sebagai pemasok sapi yang akan di feedlot sehingga mampu menjual ternak tanpa blantik (peternak sekaligus blantik) dan strategi W-T yaitu bekerjasama dengan peternak feedlot dengan produktifitas tinggi untuk meningkatkan trust. Analisis AHP dilakukan untuk menentukan prioritas strategi yang telah dibuat sehingga hasilnya dapat mendukung strategi agar peternak rakyat bergabung dengan kelompok ternak feedloting sebagai pemasok sapi yang akan di feedlot.
\end{abstract}

Kata kunci: AHP, kebijakan, pengembangan, sapi potong, strategi.

ABSTRACT. Objectives of the research were to determine strategy and establish win-win solution policy in developing beef cattle business at Ringinrejo Sub-district, Kediri Regency. Data analysis used quantitative method by using IFAS and EFAS, and then followed by AHP (Analysis Hierarchy Process). Results of the research showed that on Quadrant III, so that it requires to reconstruct the strategy, which has been performed by the stakeholders in developing the beef cattle business, due to internal factors have more weaknesses than the strength, but the existed opportunity could minimize any threat in developing the business. It results 4 strategies that include strategy S$O$, which requires to establish cooperation with the big farmerss who have already owned excellent technical management in breeding and high productivity; strategy W-O improves mutual cooperation between the farmers and central governmental institution through the increasing apparatus from social capital by offering cattle assistance, technique of maintenance that conforms to the breeders need; strategy $S$-T is joining with the group of feedloter as cattle supplier that is going to be feedlot, so that they will be able to sell the cattle without any middleman and strategy W-T is joining and cooperating with the feedloter who have high productivity in order to increase trust. In order to give priority on strategies, it followed by AHP analysis, the result showed that the breeders will join with the group of feedloting farmers as cattle supplier (feedloter).

Keywords: AHP, policy. Development, beef cattle, strategy.

\section{PENDAHULUAN}

Era revolusi industri 4.0 dan society 5.0 saat ini menuntut peternak untuk semakin meningkatkan usahanya karena produk peternakan merupakan produk pangan yang bersaing ketat dengan produk impor dari negara lain yang memiliki harga pasar jauh di bawah 
harga produk lokal. Hal ini di jelaskan oleh Kementerian Perdagangan (2013) bahwa harga paritas impor eceran daging sapi cenderung turun, sedangkan harga eceran domestik cenderung naik. Faktor yang lain mendukung kenaikan harga tersebut dikarenakan adanya program penyebaran ternak sapi oleh berbagai instansi yang pengadaannya bersumber dari ternak domestik sehingga terjadi rendahnya pasokan untuk keperluan pemotongan dan berdampak pada kenaikan harga di pasar. Di samping permasalahan tersebut meningkatnya jumlah penduduk juga berpengaruh signifikan pada kebutuhan bahan pangan. Atem dan Niko (2020) mengemukakan bahwa jika kelaparan sampai dialami oleh penduduk atau sampai terancam kondisi rawan pangan maka dapat dipastikan tidak akan ada ketenangan dan kedamaian dalam negara tersebut.

Salah satu upaya yang dilakukan oleh pemerintah dalam menyediakan jumlah ketersediaan produk peternakan untuk komoditas sapi potong adalah melalui Upaya Khusus Percepatan Populasi Sapi dan Kerbau Bunting (UPSUS SIWAB). UPSUS SIWAB merupakan salah satu program yang digalakkan oleh Kementerian Pertanian pada tahun 2016 melalui pelaksanaan Inseminasi Buatan dan pelaksanaan intensifikasi kawin alami (Kementrian Pertanian, 2016). Program ini memiliki target yaitu dapat menghasilkan sapi indukan dewasa siap bunting sebanyak empat juta ekor dan ditargetkan tingkat kebuntingan $73 \%$ atau setara tiga juta ekor betina bunting (Kementrian Pertanian, 2017). Program tersebut juga merupakan salah satu upaya yang tidak lain adalah untuk mengurangi jumlah impor dengan cara meningkatkan jumlah ketersediaan, karena selama ini antara jumlah permintaan dan ketersediaan belum tercukupi.

Rusdiana dan Soeharsono menjelaskan bahwa untuk mensukseskan program tersebut dibutuhkan dukungan dari peternak sapi potong walaupun kegiatan tersebut masih dijalankan secara tradisional dan belum bersifat komersial. Peternak juga harus mendapat jaminan bahwa usaha tersebut layak dan memberikan keuntungan. Hal ini juga diperjelas oleh Yastini (2010) bahwa peternak tradisional masih memanfaatkan pemeliharaan sapi potong berdasarkan pengalaman terdahulu dan informasi dari sesame peternak. Kegiatan penyuluhan yang yang diberikan dari pemerintah setempat belum maksimal.

Dirjen Peternakan dan Kesehatan Hewan (2019) menyebutkan dalam SK No. 189/KPTS/PK.210/F/2019 bahwa program UPSUS SIWAB diharapkan mampu meningkatkan populasi sapi dan kerbau demi tercukupinya protein hewani bagi masyarakat. Program ini juga diharapkan mampu terlaksana di semua daerah yang memiliki potensi pengembangan sapi potong rakyat walaupun usaha sapi potong di Indonesia adalah sebagai ivestasi bagi pemilik usaha, namun dengan adanya strategi yang perlu diterapkan dengan melibatkan beberapa stakeholders sehingga peternak mampu meningkatkan skala usaha dengan menambah jumlah populasi ternak.

Kabupaten Kediri merupakan salah satu wilayah yang cocok untuk pengembangan sapi potong jika dilihat dari topografi wilayahnya yang berada pada $07^{\circ} 45^{\prime}-07^{\circ} 55^{\prime}$ LS dan $111^{\circ} 05^{\prime}$ $112^{\circ} 3^{\prime}$ BT dengan ketinggian 64 meter di atas permukaan laut (Pemkab Kediri, 2014). Jenis sapi yang dipelihara oleh masyarakat Kabupaten Kediri adalah Simental, Limousin dan Peranakan Ongole. Badan Pusat Statistik (2019) Kabupaten Kediri memiliki populasi sapi potong sebanyak 223.020 ekor pada tahun 2018. Berdasarkan angka tersebut Kabupaten Kediri mampu menjadi salah satu wilayah penyumbang sapi potong nasional. Upaya yang dilakukan oleh pemerintah Kabupaten Kediri dalam meningkatkan jumlah populasi adalah meningkatkan Sumber Daya Manusia (SDM) peternak dan aparatur melalui kelembagaan, peningkatan Sumber Daya Alam (SDA) melalui 
pemanfaatan limbah hasil pertanian sebagai pakan ternak, peningkatan kerjasama dengan pihak praktisi dan akademisi dari riset dan upaya peningkatan permodalan dengan pemerintah dan lembaga keuangan melalui Kredit Usaha Rakyat.

Menurut BPS (2020) menjelaskan bahwa sumber penghasilan utama sebagian besar penduduk di Kecamatan Ringinrejo pada tahun 2019 adalah sebagai petani dan peternak sehingga sehingga kesempatan untuk mengembangkan usaha sapi potong dapat ditingkatkan. Pada penelitian ini dengan latar belakang kondisi peternak dan peternakan sapi potong maka penulis terfokus pada pembentukan strategi kebijakan pengembangan sapi potong di wilayah Ringinrejo.

\section{MATERI DAN METODE}

Penelitian dilaksanakan di Kecamatan Ringinrejo Kabupaten Kediri dengan menggunakan metode purposive sampling. BPS (2018) menunjukkan bahwa Kabupaten Kediri sebagai sentra peternakan sapi potong terbesar ke-6 se Jawa Timur dengan jumlah populasi ternak sapi potong sebanyak 203.020 ekor. Penelitian dilaksanakan selama 1 bulan dari Bulan Juli sampai Agustus 2019. Penentuan sampel dilakukan dengan metode non probability sampling dengan purposive sampling dimana peneliti tidak memberikan seluruh sampel untuk menjadi responden yaitu sebanyak 62 peternak. Hal ini sesuai penjelasan Sugiyono (2016) bahwa pengambilan sumber data pertimbangan tertentu sebab tidak sampel memiliki kriteria yang sesuai dengan teknik dengan semua dengan yang diteliti. Sehingga peneliti menetapkan kriteria-kriteria tertentu yang harus dipenuhi oleh sampel-sampel yang digunakan. Peneliti mengambil sampel untuk skala kepemilikan lebih dari 5 ST terbagi atas 2 (dua) kelomok yaitu skala menengah (4-7 ekor) dan skala besar (8-10 ekor) (Sopiyana, 2006); pengalaman beternak sekurang-kurangnya 5 tahun dan merupakan petani tanaman pangan.

Analisis data menggunakan 2 (dua) metode kuantitatif yaitu menggunakan analisis SWOT untuk untuk menentukan strategi yang akan dibuat dan analisis AHP untuk menentukan 1 kebijakan dari strategi yang tergolong dalam prioritas skala utama. Utsalina dan Primandari (2020) menjelaskan metodologi analisis SWOT menggunakan beberapa tahap meliputi:

1. Menentukan variabel yang diamati (produktivitas usaha; sistem kelembagaan peternak dengan stakeholders; akses pasar; kinerja modal; dukungan sistem logistik usaha; dan social capital), membuat daftar kekuatan, kelemahan, peluang dan ancaman (disesuaikan dengan kondisi lokasi penelitian).

2. Menentukan bobot setiap faktor mulai dari 1 (sangat penting) sampai 0 (tidak penting) sesuai data hasil wawancara.

3. Menentukan rating setiap faktor dari 5 (sangat bagus) sampai 1 (buruk) sesuai data hasil wawancara.

4. Bobot dan rating dikalikan.

5. Membuat skor tertimbang per faktor untuk menghasilkan total skor.

6. Perhitungan kombinasi strategi matrik SWOT.

7. Memilih faktor internal dan ekternal untuk menjadi kriteria dan bobot dalam pendukung keputusan.

Saediman dkk. (2015) menjelaskan bahwa prinsip penting pada analisis AHP meliputi penyusunan hirarki, penentuan prioritas, dan pemberian bobot. Pada pengisian kuisioner AHP dilakukan menggunakan teknik perbandingan berpasangan dengan menggunakan skala angka penilaian 1-9 dengan keterangan sebagai berikut:

1. Nilai 1 (atribut satu dengan yang lainnya sama penting). 
2. Nilai 3 (atribut satu sedikit lebih penting (agak kuat) dari atribut lainnya.

3. Nilai 5 (atribut satu lebih penting dari atribut lainnya.

4. Nilai 7 (atribut satu jauh lebih penting dari atribut lainnya).

5. Nilai 9 (atribut satu mutlat lebih penting dari atribut lainnya).

6. Nilai 2,4,6,8 (nilai tengah diantara dua penilaian).

7. Respirokal (jika atribut I dibandingkan dengan $\mathrm{j}$ mendapat nilai bukan nol, maka $\mathrm{j}$ jika dibandingkan dengan i mempunyai nilai kebalikannya).

Nilai-nilai numerik yang diperoleh dapat menggambarkan tingkat pengaruh maupun tingkat kepentingan relatif faktor-faktor yang ada, baik dalam kelompok SWOT maupun antar kelompok SWOT dan dapat digunakan untuk menetapkan strategi pengembangan, perencanaan strategis dan keperluan lainnya.

\section{HASIL DAN PEMBAHASAN}

\section{Strategi Pengembangan Sapi Potong di Kecamatan Ringinrejo Kediri}

Berdasarkan hasil penelitian bahwa dalam pengembangan sapi potong rakyat di Kecamatan Ringinrejo Kabupaten Kediri berada pada kuadaran III dimana faktor internal memiliki kelemahan karena aspek kelemahan lebih tinggi dibandingkan dengan aspek kekuatan sehingga sumbu $x$ untuk faktor internal memiliki hasil negatif sedangkan faktor eksternal bernilai positif karena peluang memiliki nilai tinggi dibandingkan dengan ancaman yang ada di dalam pengembangan sapi potong Ringinrejo.

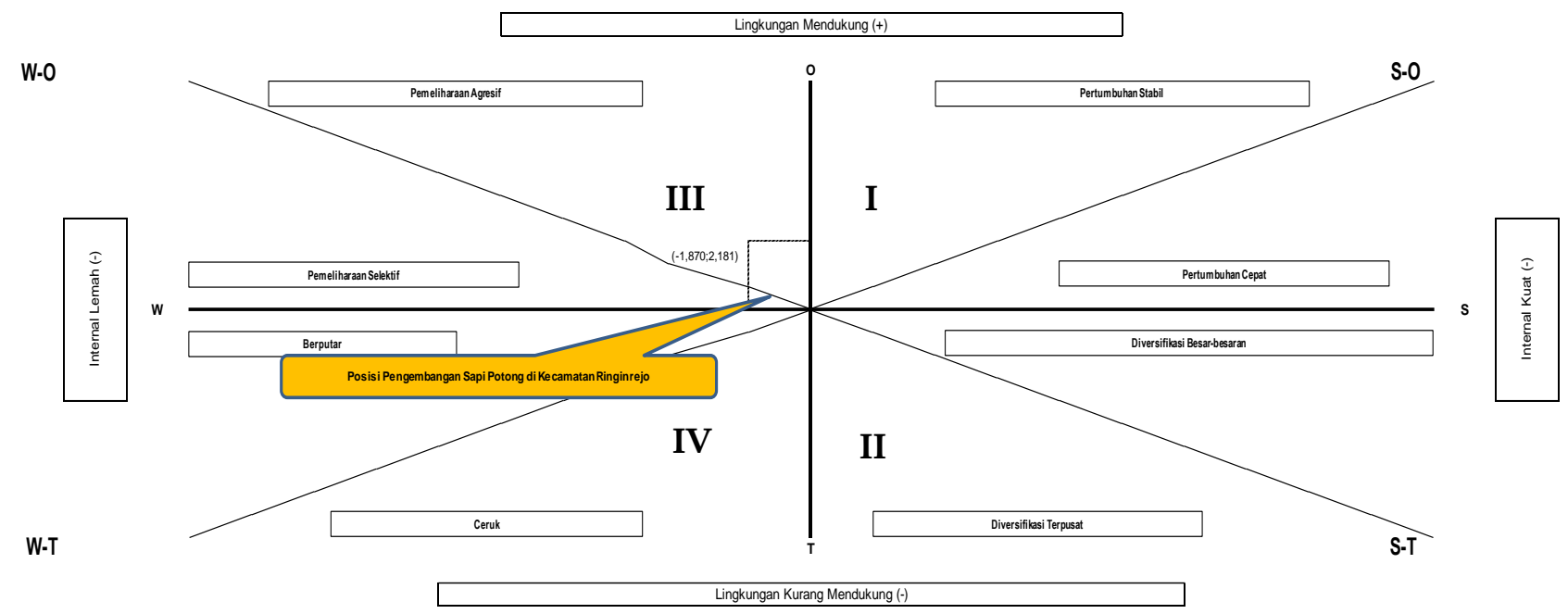

Gambar 1. Diagram Cartesius

Pada diagaram cartesius menunjukkan perlu dilakukan pemeliharaan secara selektif karena lemahnya faktor internal dari produktivitas antara lain (1) peternak masih lemah dalam penggunaan teknologi sedangkan saat ini peternak harus bersaing dengan pasar global dan impor terus masuk ke dalam negeri sehingga antara SDM dan teknologi saling bertolak belakang sehingga akses informasi peternak sangat terbatas dan minim, (2) penyuluhan dari dinas peternakan jarang dilakukan karena kurang mendapat respon postif dari peternak. Peternak berasumsi bahwa beberapa SDM dari dinas selalu bekerjasama dengan jagal sehingga peternak memiliki asumsi negatif terhadap aparat setempat. Berdasarkan kasus yang pernah dialami oleh peternak bahwa tidak sedikit bantuan tawaran yang diberikan 
oleh jagal untuk langsung membeli sapi namun ternyata jagal membeli dengan harga yang jauh lebih murah karena adanya isu yang muncul dari dinas yang tidak berpihak ke peternak justru bekerjasama dengan lembaga pemasaran dan jagal untuk mendapatkan keuntungan sendiri sehingga dari kasus tersebut membuat peternak kehilangan kepercayaan terhadap stakeholders yang seharusnya saling bersinergi meningkatkan produktifitas usaha ternak. (3) Pengetahuan peternak sangat kurang terhadap teknis pemeliharaan sapi potong dari hulu sampai hilir karena menjalankan budidaya sapi potong berdasar pengalaman yang pernah dilakukan tanpa didukung dengan ilmu pengetahuan yang didapatkan dari pendidikan formal, (4) pemahaman peternak terhadap pejantan unggul kurang sehingga angka inbreeding juga tinggi karena pejantan unggul dikawinkan dengan ternak di satu wilayah kecamatan Ringinrejo, (5) pengetahuan kurang terhadap penyakit dan cara penanangannya.

Tabel 1. Analisis IFAS dan EFAS

\begin{tabular}{|c|c|c|}
\hline $\begin{array}{l}\text { INTERNAL/ } \\
\text { EKTERNAL }\end{array}$ & $\begin{array}{l}\text { STRENGTH } \\
\text { 1. Kontinyuitas ketersediaan } \\
\text { pakan di Kecamatan } \\
\text { Ringinrejo } \\
\text { 2. Permintaan Produksi Sapi } \\
\text { Potong } \\
\text { 3. Kenaikan bobot badan sapi } \\
\text { saat dijual sesuai dengan } \\
\text { permintaan pasar } \\
\text { 4. Harga Inseminasi Buatan } \\
\text { 5. Frekuensi pelaksanaan IB } \\
\text { 6. BCS ternak dimana standar } \\
\text { BCS normal bahkan tinggi (3,5- } \\
\text { 5) } \\
\text { 7. Integrasi dengan usaha tani } \\
\text { tanaman pangan mendukung } \\
\text { penambahan modal usaha sapi } \\
\text { potong kabutuhan } \\
\text { 8. Berdasarkan antara } \\
\text { keduanya apakah an antan } \\
\text { usahatani tanaman pangan } \\
\text { dan usaha ternak saling } \\
\text { berkaitan luar di luar } \\
\text { 9. Pemasaran luas } \\
\text { Ringinrejo } \\
\text { 10. Motivasi beternak } \\
\text { 11. Modal usaha }\end{array}$ & $\begin{array}{l}\text { WEAKNESS } \\
\text { 1. Frekuensi penggunaan } \\
\text { teknologi di era revolusi } \\
\text { industri } 4.0 \\
\text { 2. Penyuluhan di Kecamatan } \\
\text { Ringinrejo } \\
\text { 3. Pengetahuan peternak } \\
\text { terhadap pengolahan pakan } \\
\text { dan jenis sumber pakan } \\
\text { 4. Pengetahuan peternak } \\
\text { terhadap reproduksi } \\
\text { 5. Pemahaman peternak } \\
\text { terhadap kriteria pejantan } \\
\text { unggul } \\
\text { 6. Pemahaman } \\
\text { terhadap jenis penyakit dan } \\
\text { pengendaliannya } \\
\text { 7. Kegiatan penyuluhan tentang } \\
\text { usaha ternak sapi potong } \\
\text { 8. Keinginan peternak untuk } \\
\text { bergabung dengan kelompok } \\
\text { ternak } \\
\text { 9. Kerjasama peternak dengan } \\
\text { dinas setempat } \\
\text { 10. Jarak desa dengan konsumen, } \\
\text { pusat kota dan pasar hewan } \\
\text { 11. Jangkauan peternak ke pasar } \\
\text { hewan } \\
\text { 12. Kondisi jalan di Kecamatan } \\
\text { Ringinrejo } \\
\text { 13. Ketersediaan angkutan umum } \\
\text { 14. Akses internet dan signal } \\
\text { telepon } \\
\text { 15. Fasilitas RPH, pasar hewan, } \\
\text { akses dan fasilitas }\end{array}$ \\
\hline
\end{tabular}




\begin{tabular}{|c|c|c|}
\hline & & $\begin{array}{l}\text { 16. Keinginan untuk bergabung } \\
\text { dengan kemitraan/ kerjasama } \\
\text { dengan investor luar dengan } \\
\text { kontrak formal } \\
\text { 17. Keinginan peternak } \\
\text { mengembangkan usaha } \\
\text { melalui lembaga keuangan } \\
\text { 18. Bentuk tolong-menolong } \\
\text { antar peternak } \\
\text { 19. Peternak membantu ternak } \\
\text { milik orang lain yang } \\
\text { mengalami kasus reproduksi } \\
\text { 20. Tindakan proaktif (apakah } \\
\text { setiap orang memiliki } \\
\text { empathy dan proaktif kepada } \\
\text { sesama peternak) } \\
\text { 21. Partisipasi peternak } \\
\text { (hubungan dalam kelompok } \\
\text { sosial) } \\
\text { 22. Peternak tidak memiliki } \\
\text { kelompok informal yang } \\
\text { berkaitan dengan usahaternak }\end{array}$ \\
\hline $\begin{array}{l}\text { OPPORTUNITY } \\
\text { 1. Peluang IB sexing } \\
\text { 2. Adanya dukungan dari } \\
\text { lembaga-lembaga pemerintah } \\
\text { pusat dan lembaga lainnya } \\
\text { dalam rangka peningkatan } \\
\text { aparatur } \\
\text { 3. Pemenuhan permintaan } \\
\text { tenaga kerja } \\
\text { 4. } \begin{array}{l}\text { Perkembangan } \\
\text { Komunikasi }\end{array}\end{array}$ & $\begin{array}{l}\text { S-O } \\
\text { Membangun kerjasama dengan } \\
\text { peternak besar yang memiliki } \\
\text { manajemen teknis pemeliharaan } \\
\text { sapi potong yang sudah baik dan } \\
\text { tingkat produktifitas usaha tinggi }\end{array}$ & $\begin{array}{l}\text { W-O } \\
\text { Memperbaiki hubungan peternak } \\
\text { dengan lembaga pemerintah pusat } \\
\text { melalui peningkatan aparatur dari } \\
\text { modal sosial dengan memberikan } \\
\text { bantuan ternak, teknis } \\
\text { pemeliharaan sesuai dengan yang } \\
\text { dibutuhkan peternak }\end{array}$ \\
\hline $\begin{array}{l}\text { THREAT } \\
\text { 1. Peran blantik tinggi } \\
\text { 2. Informasi pasar dikuasai oleh } \\
\text { blantik } \\
\text { 3. Kelompok ternak feedloting } \\
\text { memiliki pasar yang luas }\end{array}$ & $\begin{array}{l}\text { S-T } \\
\text { Bergabung dengan kelompok } \\
\text { ternak feedloting sebagai pemasok } \\
\text { sapi yang akan di feedlot sehingga } \\
\text { mampu menjual ternak tanpa } \\
\text { blantik (peternak sekaligus } \\
\text { blantik) }\end{array}$ & $\begin{array}{l}\text { W-T } \\
\text { Bekerjasama dengan peternak } \\
\text { feedlot dengan produktifitas tinggi } \\
\text { untuk meningkatkan trust }\end{array}$ \\
\hline
\end{tabular}

Sumber: Data primer diolah, September 2019.

Berdasarkan hasil analisis IFAS dan EFAS diperoleh 4 strategi yang akan dilaksanakan untuk S-O dimana membangun kerjasama dengan peternak besar yang memiliki manajemen teknis pemeliharaan sapi potong yang sudah baik dan tingkat produktifitas usaha tinggi, peternak yang dimaksud adalah peternak yang memiliki skala kepemilikan besar serta permodalan yang kuat dan memiliki manajemen teknis pemeliharaan yang sudah baik serta dengan populasi yang banyak maka 
produktifitas usaha semakin baik, dan usaha ternak sapi potong sebagai pekerjaan utama.

Strategi W-O yaitu memperbaiki hubungan peternak dengan lembaga pemerintah daerah dan pusat melalui peningkatan aparatur dari modal sosial dengan memberikan bantuan ternak, teknis pemeliharaan sesuai dengan yang dibutuhkan peternak. Strategi tersebut dibuat karena modal sosial peternak terhadap lembaga pemerintahan sangat lemah terutama pada kepercayaan, peternak tidak percaya terhadap bantuan yang diberikan oleh pihak manapun karena berdasarkan pengalaman peternak yang justru malah menurunkan produktifitas usaha jika dibantu oleh lembaga pemerintah setempat seperti kualitas bibit yang diberikan untuk peternak tidak semua bibit unggul dan peternak berasumsi bahwa pemerintah bekerjasama dengan jagal dimana keberadaan jagal bagi peternak mampu merusak harga jual ternak. Berdasarkan pengalaman yang pernah diperoleh peternak maka kredibilitas peternak terhadap pemerintah setempat sangat rendah, sehingga asumsinya peternak lebih baik menjalankan usaha sesuai dengan kemampuan finansial yang ada bahkan beberapa responden memelihara ternak hanya sebagai investasi sehingga perlu adanya peningkatan SDM untuk aparatur dalam menguatkan modal sosial terutama membangun tingkat kepercayaan peternak.

Strategi S-T dimana bergabung dengan kelompok ternak feedloting sebagai pemasok sapi yang akan digemukkan sehingga mampu menjual ternak tanpa blantik (peternak sekaligus blantik). Strategi ini dibuat karena hampir seluruh peternak menjual sapinya ke blantik, sehingga angka ketergantungan peternak terhadap blantik sangat tinggi karena keterbatasan pengetahuan peternak terhadap harga pasar dan jarak tempuh pemeliharaan ke pasar hewan juga jauh sehingga peternak memilih blantik sebagai lembaga pemasaran untuk menjual ternaknya di pasar hewan. Di
Kecamatan Ringinrejo terdapat kelompok ternak yang sudah mandiri namun sistem budidayanya adalah feedloting sehingga cukup cepat untuk dilakukan proses penjualan ternak dan peternak juga melakukan penjualan sendiri ke pasar hewan yang artinya peternak juga sekaligus menjadi blantik, sehingga dengan strategi ini peternak diharapkan mampu meningkatkan posisi tawar dengan cara menjadi blantik untuk usahanya sendiri.

Strategi W-T adalah membentuk kerjasama dengan peternak feedlot dengan produktifitas tinggi untuk meningkatkan trust. Peternakan feedlot yang ada di Kecamatan Ringinrejo termasuk dalam kategori peternak yang sudah berdaya dari segi finansial dan mampu memasarkan ternaknya tanpa melalui lembaga pemasaran sehingga peternak juga merangkap sebagai lembaga pemasaran, dan dengan adanya kelompok ternak yang memiliki sistem permodalan kuat harapannya mampu membantu peternak yang masih memiliki populasi sedikit karena aspek finansial yang rendah sehingga peternak yang memelihara sapi potong untuk pembibitan mampu memasok ke peternak feedlot untuk dilakukan proses penggemukkan. Peternak feedlot tidak perlu mencari stock sapi potong dari daerah lain karena akan dipasok dari peternak kecil di Kecamatan Ringinrejo.

Berdasarkan hasil analisis Analysis Hierarchy Process (AHP) menunjukkan bahwa dari 4 strategi yang telah dibuat dari masingmasing aspek sehingga diperoleh hasil analisis pada Tabel 2 . 
Tabel 2. Hasil Analisis AHP

\begin{tabular}{|c|c|c|c|c|c|c|c|c|}
\hline Srategi & $\begin{array}{l}\text { Produktivitas } \\
\text { Usaha Sapi } \\
\text { Potong }\end{array}$ & $\begin{array}{c}\text { Sistem } \\
\text { Kelembagaan } \\
\text { Peternak } \\
\text { dengan } \\
\text { stakeholders }\end{array}$ & $\begin{array}{c}\text { Akses } \\
\text { Pasar }\end{array}$ & $\begin{array}{c}\text { Kinerja } \\
\text { Modal }\end{array}$ & $\begin{array}{c}\text { Dukungan } \\
\text { Sistem } \\
\text { Logistik }\end{array}$ & $\begin{array}{l}\text { Modal } \\
\text { Sosial }\end{array}$ & Eigen & Prioritas \\
\hline $\begin{array}{l}\text { Membangun kerjasama } \\
\text { dengan peternak besar } \\
\text { yang memiliki manajemen } \\
\text { teknis pemeliharaan sapi } \\
\text { potong yang sudah baik } \\
\text { dan tingkat produktifitas } \\
\text { usaha tinggi }\end{array}$ & 0,294 & 0,058 & 0,086 & 0,059 & 0,124 & 0,060 & 0,092 & IV \\
\hline $\begin{array}{l}\text { Memperbaiki hubungan } \\
\text { peternak dengan lembaga } \\
\text { pemerintah pusat melalui } \\
\text { peningkatan aparatur dari } \\
\text { modal sosial dengan } \\
\text { memberikan bantuan } \\
\text { ternak, teknis } \\
\text { pemeliharaan sesuai } \\
\text { dengan yang dibutuhkan } \\
\text { peternak }\end{array}$ & 0,227 & 0,329 & 0,184 & 0,336 & 0,269 & 0,141 & 0,261 & III \\
\hline $\begin{array}{l}\text { Bergabung dengan } \\
\text { kelompok ternak feedloting } \\
\text { sebagai pemasok sapi yang } \\
\text { akan di feedlot sehingga } \\
\text { mampu menjual ternak } \\
\text { tanpa blantik (peternak } \\
\text { sekaligus blantik) }\end{array}$ & 0,317 & 0,339 & 0,435 & 0,320 & 0,353 & 0,505 & 0,379 & I \\
\hline $\begin{array}{l}\text { Bekerjasama dengan } \\
\text { peternak feedlot dengan } \\
\text { produktifitas tinggi untuk } \\
\text { meningkatkan trust }\end{array}$ & 0,163 & 0,274 & 0,295 & 0,286 & 0,254 & 0,294 & 0,268 & II \\
\hline
\end{tabular}

Sumber: Data primer diolah, September 2019.

Berdasarkan hasil analisis dari strategi yang telah diperoleh dari analisis IFAS dan EFAS yang kemudian dilanjutkan analisis AHP bahwa strategi yang menjadi prioritas utama dalam pengembangan sapi potong di Kecamatan Ringinrejo Kabupaten Kediri adalah bergabung dengan kelompok ternak feedloting sebagai pemasok sapi yang akan di feedlot sehingga mampu menjual ternak tanpa blantik (peternak sekaligus blantik) karena kelompok ternak feedloting memiliki pangsa pasar yang lebih luas dan peternak juga berperan sebagai blantik sehingga lebih mampu menentukan posisi tawar dibandingkan harus menyerahkan semuanya ke blantik.

Prioritas yang ke II adalah dengan strategi membentuk kerjasama dengan peternak feedlot 
dengan produktifitas tinggi untuk meningkatkan trust. Kepercayaan yang dibangun antara peternak rakyat dan peternak feedlot harus dibangun sejak awal bekerjasama karena dalam dunia bisnis kepercayaan merupakan hal yang penting. Strategi meningkatkan trust dan produktifitas ternak dengan cara peternak feedlot memberikan sosialisasi serta membantu dalam proses penggemukan ternak, untuk membangun kepercayaan peternak maka peternak feedlot harus memberikan bukti nyata terlebih dahulu.

\section{KESIMPULAN}

Kesimpulan pada penelitian ini yaitu strategi yang diprioritaskan untuk peternak sapi potong di Kecamatan Ringinrejo Kabupaten Kediri dengan bergabung dengan kelompok ternak feedloting sebagai pemasok sapi yang akan di feedlot sehingga mampu menjual ternak tanpa blantik (peternak sekaligus blantik); bekerjasama dengan peternak feedlot dengan produktifitas tinggi untuk meningkatkan trust. Diharapkan strategi yang diprioritaskan tersebut dapat menjadi masukan dalam perumusan kebijakan terhadap pengembangan peternakan sapi potong di Kecamatan Ringinrejo Kabupaten Kediri.

\section{KONFLIK KEPENTINGAN}

Bersama pernyataan ini penulis dan seluruh anggota tim peneliti menyatakan tidak sedang memiliki konflik kepentingan yang berhubungan dengan keuangan, pribadi, atau lainnya dengan orang atau organisasi lain yang terkait dengan materi yang dibahas dalam naskah.

\section{UCAPAN TERIMA KASIH}

Terima kasih kepada LPPM Universitas Brawijaya dan Fakultas Peternakan Universitas Brawijaya yang telah memberikan ijin penelitian serta memberikan bantuan dalam bentuk materil dalam proses pelaksanaan.

\section{DAFTAR PUSTAKA}

Atem dan N. Niko. 2020. Persoalan Kerawanan Pangan pada Masyarakat Miskin di Wilayah Perbatasan Entikong (Indonesia-Malaysia) Kalimantan Barat. Jurnal Surya Masyarakat. 2(2) : 94-104.

Badan Pusat Statistik. 2018. Populasi Sapi Potong Menurut Kabupaten/Kota di Jawa Timur Tahun 2009-2017.

Badan Pusat Statistik. 2019. Ternak Menurut Kabupaten/Kota Daerah Provinsi Jawa Timur, 2017-2018.

Badan Pusat Statistik. 2020. Kecamatan Ringinrejo dalam Angka 2020.

Dirjen Peternakan dan Kesehatan Hewan. 2019. Pedoman Pelaksanaan Upaya Khusus Percepatan Peningkatan Populasi Sapi dan Kerbau Bunting Tahun Anggaran 2019. SK No. 189/KPTS/PK.210/F/2019.

Kementrian Perdagangan. 2013. Analisis FaktorFaktor yang Mempengaruhi Harga Eceran Daging Sapi Dalam Negeri. Makalah. Pusat Kebijakan Perdagangan Dalam Negeri Badan Pengkajian dan Pengembangan Kebijakan Perdagangan.

Kementrian Pertanian. 2016. Upaya Khusus Percepatan Peningkatan Populasi Sapi dan Kerbau Bunting. No. 48/Permentan/PK.210/10/2016.

Kementrian Pertanian. 2017. Perubahan Atas Peraturan Menteri Pertanian Nomor 49/Permentan/Pk.440/10/2016 Tentang Pemasukan Ternak Ruminansia Besar Ke Dalam Wilayah Negara Republik Indonesia. No 2/Permentan/Pk.440/2/2017.

Pemerintah Kabupaten Kediri. 2014. Profil Kabupaten Kediri. https://www.kedirikab.go.id/index.php?opti on=com_content\&view=article\&id=1526\&Ite $\underline{\operatorname{mid}=987 .}$. 
Rusdiana dan Soeharsono. 2017. Program Siwab Untuk Meningkatkan Populasi Sapi Potong dan Nilai Ekonomi Usaha Ternak. Forum Penelitian Agro Ekonomi. 35(2) : 125-137.

Saediman, H., M.A. Limi., dan Y.Indarsyih. 2015. Aplikasi SWOT-AHP untuk Mengalisis FaktorFaktor yang Mempenbgaruhi Pengembangan Komoditas Padi Sawah di Provinsi Sulawesi Tenggara. Prosiding Seminar Nasional Agribisnis. Kendari: 9 Maret 2015. Hal: 416426.

Sopiyana, S. 2006. The Analysis of Application of Technical Management on Various Small Holder Dairy Farm Scale in Garut Regency West Java. Animal Production. 8(3) : 216-225.
Sugiyono. 2016. Metode Penelitian Kuantitatif, Kualitatif, dan R\&D. Alfabeta. Bandung.

Utsalina, D.S., dan L.A. Primandari. 2020. Analisis SWOT dalam Penentuan Bobot Kriteria pada Pemilihan Strategi Pemasaran Menggunakan Analytic Network Process. Jurnal Ilmiah Teknik Informatika. 14(1) : 41-50.

Yastini, N.N. 2010 . Masalah Yang dihadapi Kelompok Ternak dalam Mengembangkan Agribisnis Ternak Sapi. Jurnal DWIJENAGRO. 1(1):49-55. 